\title{
12. INTEGRATED CALCAREOUS PLANKTON BIOSTRATIGRAPHY AND CYCLOSTRATIGRAPHY AT SITE 964 ${ }^{1}$
}

\author{
R. Sprovieri, ${ }^{2}$ E. Di Stefano, ${ }^{2}$ M. Howell,${ }^{3}$ T. Sakamoto, ${ }^{4}$ A. Di Stefano, ${ }^{5}$ and M. Marino ${ }^{6}$
}

\begin{abstract}
Twenty-one calcareous plankton biostratigraphic events have been identified in Ocean Drilling Program Site 964, between the upper part of the Piacenzian and the Holocene and correlated to the relative abundance fluctuations of Globigerinoides spp. and the oxygen isotope stages. Our study essentially supports previous investigations on coeval Mediterranean sequences with one (minor) difference: the last occurrence of Discoaster brouweri is correlated with oxygen isotopic stage/relative abundance fluctuation 71 instead of 73. Correlation of the sequence of Site 964 with other Pliocene and Pleistocene sequences studied in the Mediterranean basin in the last years proves that the reported biostratigraphic events are essentially synchronous. Only minor discrepancies exist between the proposed ages in this paper and the ages reported by other authors. The chronostratigraphic subdivision of the studied interval is reported according to the accepted definition of the chronostratigraphic boundaries.
\end{abstract}

\section{INTRODUCTION}

The recently defined late Pliocene Gelasian stage (Rio et al., 1994) has its global boundary stratigraphic section and point (GSSP) in the Monte San Nicola section, outcropping in southern Sicily, near the Gela village (Fig. 1). Integrated calcareous plankton biostratigraphy, magnetostratigraphy, and relative abundance fluctuations of Globigerinoides spp. were published by Channell et al. (1992) and discussed by Sprovieri (1993). To correlate this land section to the deep-sea record, we studied the nearest Ocean Drilling Program (ODP) Leg 160 Site in the Eastern Mediterranean that encompasses the Gelasian, Site 964. At this site, oxygen and carbon isotopic records are also available (Howell et al., Chap. 13, this volume); the detailed correlation between the two sections provides a more complete stratigraphic record of the interval covered by the Gelasian stage.

Cyclostratigraphic interpretation of the studied interval was obtained by the relative abundance fluctuations of Globigerinoides spp. These fluctuations were compared and correlated with the oxygen isotopic stages.

\section{MATERIAL}

ODP Leg 160 Site 964 is located at the foot of the Calabrian Ridge in a water depth of $3650 \mathrm{~m}\left(36^{\circ} 15.62^{\prime} \mathrm{N}, 17^{\circ} 45.025^{\prime} \mathrm{E}\right.$; Fig. 1$)$, about $350 \mathrm{~km}$ southeast of the Monte San Nicola section. Five holes were cored at this site. The studied sequence is represented by a composite of different segments of the five holes. The revised meter corrected depth scale (rmcd) was formulated postcruise by Sakamoto et al. (Chap. 4, this volume).

The lithologic sequence is represented essentially by a nannofossil ooze, but turbidites are present at some intervals. In particular, the thick turbiditic interval between 70.42 and 72.92 rmcd provides an

${ }^{1}$ Robertson, A.H.F., Emeis, K.-C., Richter, C., and Camerlenghi, A. (Eds.), 1998. Proc. ODP, Sci. Results, 160: College Station, TX (Ocean Drilling Program).

${ }^{2}$ Department of Geology and Geodesy, Corso Tukory, 131, 90134 Palermo, Italy. rspr@mbox.unipa.it

${ }^{3}$ College of Science and Mathematics, South Carolina, Columbia, SC 29208, U.S.A. Japan.

${ }^{4}$ Department of Earth and Planetary Sciences, Hokkaido University, Sapporo, 060,

${ }^{5}$ Institute of Geology and Geophysics, Corso Italia, 55, 95129 Catania, Italy.

${ }^{6}$ Department of Geology and Geophysics, Via E. Orabona, 4, 70125 Bari, Italy. apparent increase in the thickness of an isotopic stage. Between 42.80 and $54.10 \mathrm{rmcd}$, repeated turbiditic intervals made it impossible to recover samples usable for a detailed analysis. Below $105.16 \mathrm{rmcd}$, several turbidites are also present. As a consequence, detailed biostratigraphy and cyclostratigraphy are hampered by the possibility of reworking. Therefore, this part of the borehole was discarded from our analysis. In the studied sequence, 59 sapropels were identified (Sakamoto et al., Chap. 4, this volume), 58 of which are included in the studied interval. Their stratigraphic position is reported in the lithology column of Figure 2. Sampling for the study was performed at an interval of $20 \mathrm{~cm}$.

\section{METHODOLOGY}

Samples for foraminifer analysis were washed on a $63-\mu \mathrm{m}$ sieve. Only half of the residue of each sample was used for the study of the foraminifer assemblage. The other part of the residue was used for isotopic analysis. Generally, the same samples used to obtain the isotopic data were studied for the foraminifer analysis, but sporadic samples too small for this work were analyzed for isotopes only. Conversely, samples in which specimens of Globigerina bulloides were rare were studied only paleontologically.

Only the greater than $125-\mu \mathrm{m}$ residue was used, and all residue of the samples was analyzed to identify biostratigraphic markers. For quantitative analyses of the split residues, at least 300 planktonic foraminifers specimens were identified and counted, with reference to the taxonomic units reported in Table 1. The faunal curve used for cyclostratigraphic interpretation was obtained by plotting the sum of the percent values of all the Globigerinoides species present in each sample. Figures 2 through 6 display the relative abundance fluctuations of the most common taxonomic units. Benthic foraminifers were not studied, because they are rare or absent. Benthic foraminifers, including some shallow-water species, were common only in the turbiditic intervals.

Preparation of the smear slides for light microscope analysis of calcareous nannofossils followed standard techniques. The distribution pattern of selected calcareous nannofossil markers was determined by light microscope (transmitted light and crossed nicols) at about 1000× magnification. Only the first occurrence (FO) of Emiliania huxleyi was identified by scanning electron microscope analysis. The same unprocessed material used to prepare the smear slides was smeared on a stab. No removal of the biogenic material was performed to maintain the natural status of the nannofossil associations.

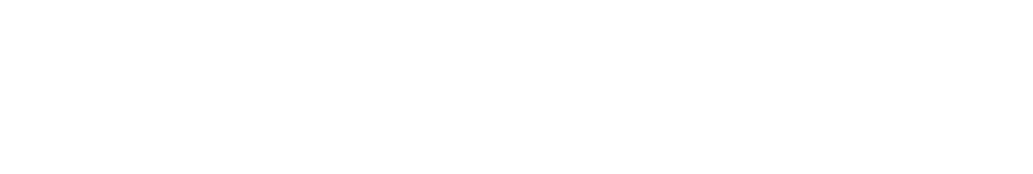




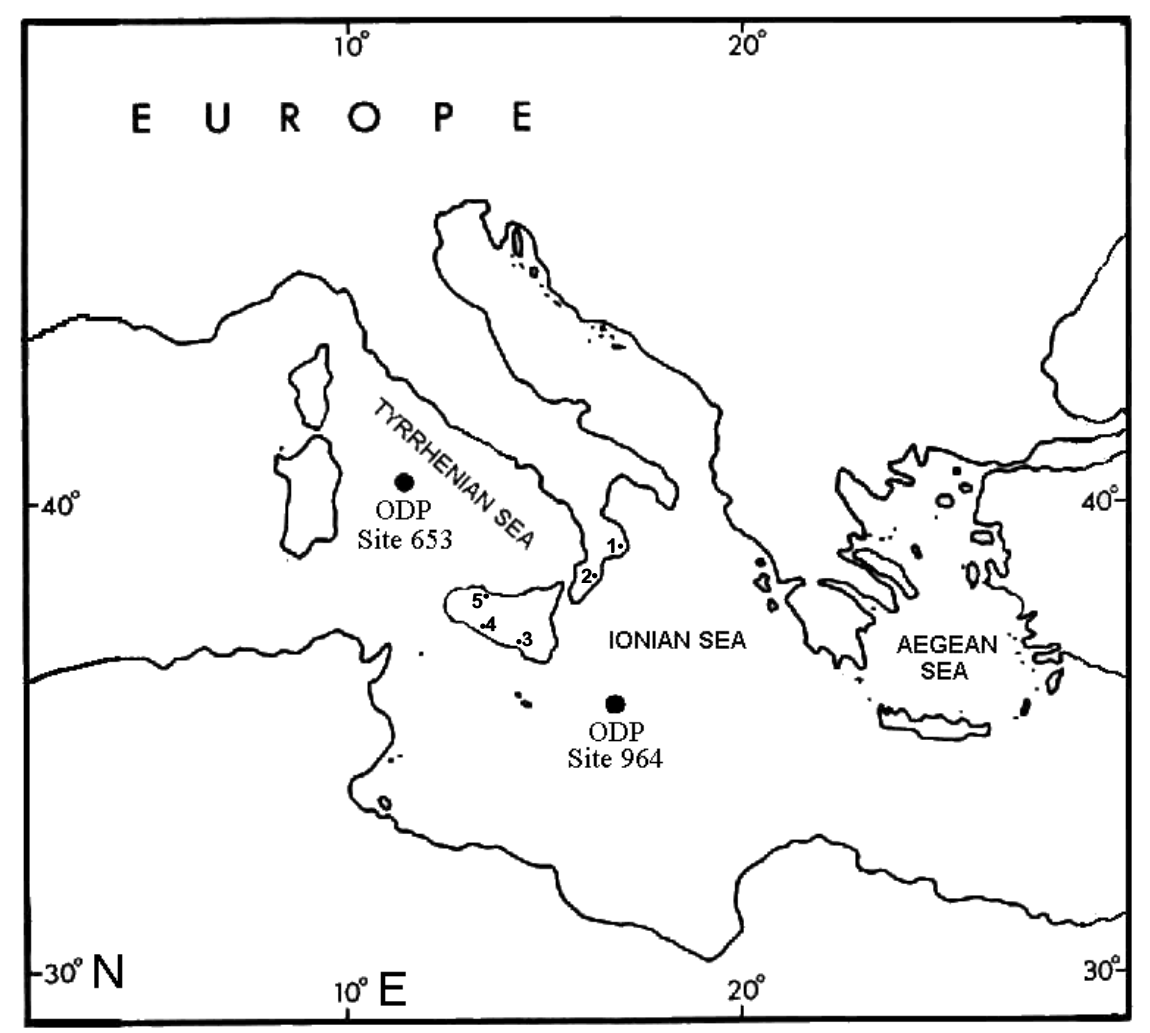

Abundance data were collected using the methodology described by Rio et al. (1990) to facilitate correlation to data collected from other Mediterranean sequences (e.g., ODP Site 653, Tyrrhenian Sea; land sections of southern Sicily, Monte San Nicola and Capo Rossello). The following counting methods were used:

$1=$ Index species vs. the total assemblages to detect the E. huxleyi FO and Pseudoemiliania lacunosa last occurrence (LO). Counts were restricted to the first 300 and to the first 500 nannofossils, respectively.

$2=$ Index species vs. a fixed number of taxonomically related forms. This was used to detect the abundance patterns of Discoaster markers (100 asteroliths), Calcidiscus macintyrei (100 Calcidiscus), Helicosphaera sellii (50 helicoliths), mediumsized Gephyrocapsa (300 placoliths $>3 \mu \mathrm{m})$, Large Gephyrocapsa (100 gephyrocapsids $>4 \mu \mathrm{m})$, and Gephyrocapsa sp. 3 (100 medium-sized Gephyrocapsa).

$3=$ Number of specimens of a taxon in a prefixed area of the slide $\left(4.52 \mathrm{~mm}^{2}\right)$. This was utilized to obtain the total accumulation of the genus Discoaster along the record.

Specimens of the planktonic foraminifer Globigerina bulloides were analyzed for $\delta^{18} \mathrm{O}$. Samples from the $>250-\mu \mathrm{m}$ residue fraction were picked and treated sonically in methanol for $\sim 2 \mathrm{~min}$. Samples were analyzed at the University of South Carolina Stable Isotope Laboratory using a VG OPTIMA stable isotope ratio mass spectrometer equipped with an automated Isocarb preparation system. All stable isotope values are reported relative to the Peedee Belemnite standard in per million (\%o) units using the $\delta$ notation.

\section{BIOSTRATIGRAPHY}

\section{Planktonic Foraminifers}

The Mediterranean zonation of Cita (1973, 1975), amended by Sprovieri (1992), was used. The planktonic foraminifer assemblage is rich and well diversified, with well-represented marker species. In the Pleistocene segment, the FO of Globorotalia truncatulinoides excelsa could not be detected, as the integrated calcareous plankton biostratigraphy indicates its FO is well above the FO recognized in other Mediterranean sections. Therefore, the entire Quaternary stratigraphic interval was assigned to a nonsubdivided Globigerina cariacoensis-Globorotalia truncatulinoides excelsa Zone.

The basal interval of the studied section, up to $82.61 \mathrm{rmcd}$, falls within the MPI5a biozone, as indicated by the presence of Globorotalia bononiensis (Fig. 2). This species is never abundant and occurs discontinuously within the analyzed samples. It disappears in Sample 160-964C-8H-4, 10-12 cm (82.61 rmcd), where the MPl5a/MPl5b boundary was recognized. In the MP15a biozone, specimens of Globorotalia crassaformis s.l. (G. crassaformis, G. aemiliana, G. crotonensis, G. crassacrotonensis, and G. viola) are present and are predominantly left coiling. Dominance of right-coiling $G$. crassaformis s.l. specimens was found at 102.24, 102.09, 100.86, 98.82, and $97.44 \mathrm{rmcd}$ (Fig. 4). The repeated, high-frequency coiling shifts of this species in the lower part of the MP15a biozone are a useful, second-order biostratigraphic tool for enhancing the biostratigraphic resolution in this part of the upper Piacenzian stratigraphic sequence. In the lower part of this biozone, the Pliocene FO of essentially left-coiling specimens of Neogloboquadrina atlantica occurs (Sample 160$964 \mathrm{E}-6 \mathrm{H}-2,89-91 \mathrm{~cm}, 98.82 \mathrm{rmcd})$. In this sample the species is abundant, with well-developed, encrusted specimens. As in other Mediterranean sections, Globigerinoides quadrilobatus and Globigerinoides obliquus s.l. are more continuously present in the lower part of this biozone (Fig. 3; see also Sprovieri, 1992).

The segment between 82.61 and 66.86 rmcd represents the MP15b biozone, defined at the top by the FO of Globorotalia inflata. This biostratigraphic interval is characterized by the absence of the $G$. inflata group taxa. The uppermost level with common specimens of $N$. atlantica (Sample 160-964E-4H-3, 100-102 cm, $76.52 \mathrm{rmcd}$ ) is recorded in the lower part of this biozone.

The MP16 biozone, defined at the top by the first common occurrence (FCO) of Neogloboquadrina pachyderma left coiling, covers the stratigraphic interval between 66.86 and 58.12 rmcd. Left-coiling specimens of N. pachyderma are rare throughout the Pliocene-Pleis- 


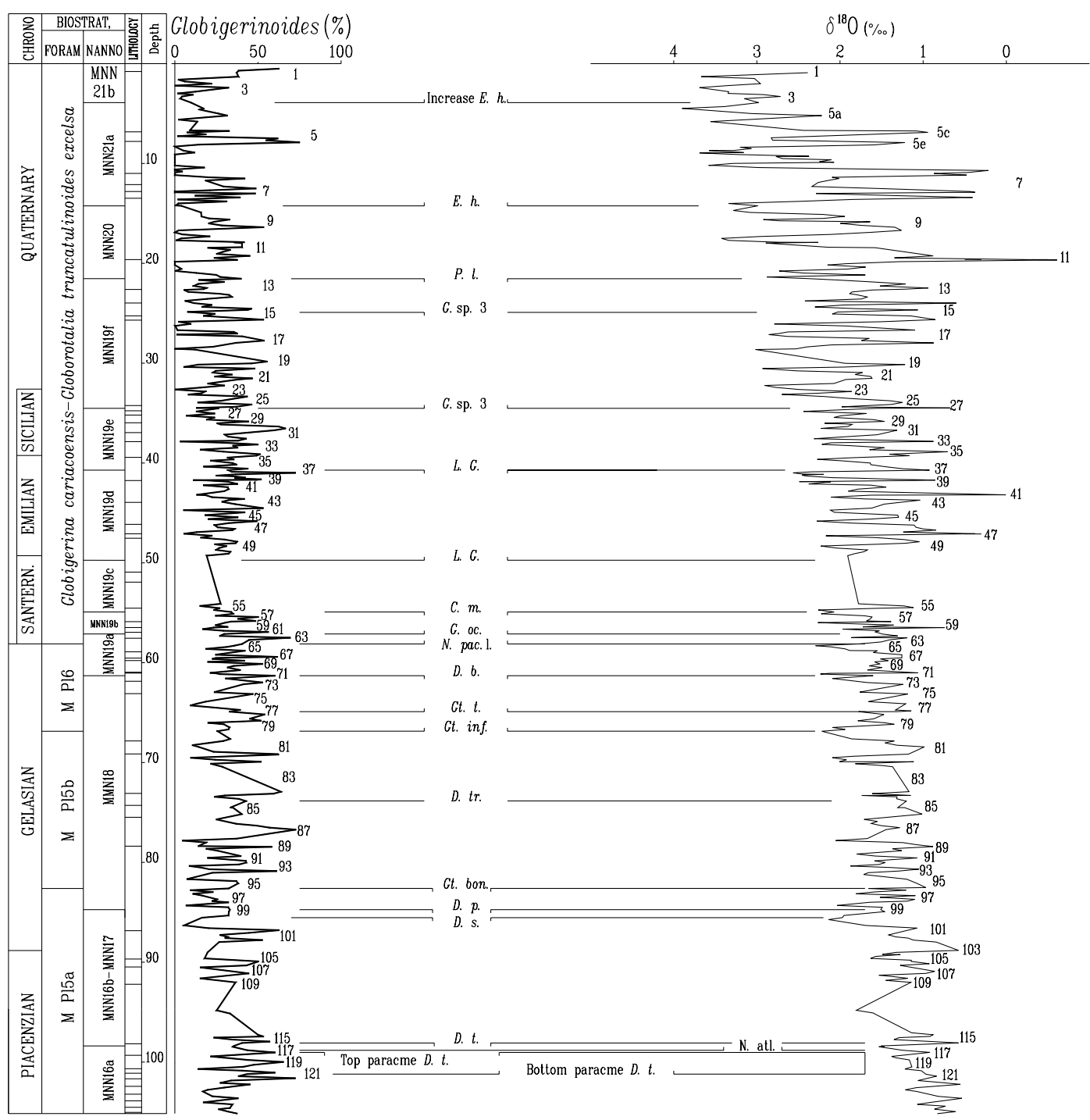

Figure 2. Calcareous plankton biostratigraphy, relative abundance fluctuations of Globigerinoides spp., and oxygen isotope stages in the studied sequence at Site 964. "Warm" fluctuations are labeled with odd numbers. E. h. = Emiliania huxleyi; P. l. = Pseudoemiliania lacunosa; G. sp. $3=$ Gephyrocapsa sp. $3 ;$ L. G. = Large Gephyrocapsa; C. m. = Calcidiscus macintyrei; G. oc. = medium-sized Gephyrocapsa; . pac. s. = Neogloboquadrina pachyderma left coiling; D. $b .=$ Discoaster brouweri; Gt. t. = Globorotalia truncatulinoides; Gt. inf. = Globorotalia inflata; D. tr. = Discoaster triradiatus; Gt. bon. = Globorotalia bononiensis; D. $p .=$ Discoaster pentaradiatus; $D . s .=$ Discoaster surculus; D. $t .=$ Discoaster tamalis; $N$. atl $=$ Neogloboquadrina atlantica . Stratigraphic position of the sapropels is indicated by horizontal lines in the lithology column, on the left.

tocene stratigraphic sequence at Site 964 (Fig. 5). We identified the base of the Globigerina cariacoensis Zone, defined by the FCO of $N$. pachyderma left coiling, in recognition of the level in which the first relative increase in abundance of the marker occurs, compared with the values recorded in the underlying strata. This is also the oldest level in which left-coiling $N$. pachyderma represents about $50 \%$ of the total $N$. pachyderma population.

The planktonic foraminifer biostratigraphic resolution is poor in the Mediterranean Pleistocene (Sprovieri, 1992). For this microfossil group, the distinctive faunal trend at Site 964 (as in other coeval sequences), is the general upsection increase of the "cold" species $(N$. pachyderma, Turborotalita quinqueloba, and Globorotalia scitula; Figs. 5, 6).

\section{Calcareous Nannofossils}

The zonal scheme of Rio et al. (1990), extensively used in the Pliocene-Pleistocene Mediterranean record (Channell et al., 1992; Di
Stefano et al., 1993; Castradori, 1993) and during the Leg 160 cruise, was adopted here. The only change is the recognition of the upper boundary of Biozone MNN16a according to the definition of Sprovieri et al. (1994) and Di Stefano (Chap. 8, this volume). The calcareous nannofossil biostratigraphy of the Site 964 sequence is shown in Figure 7.

Calcareous nannofossils are abundant to common in the smear slides. Preservation is generally good, but overgrowths and broken specimens consistently occur in samples where silt and volcanic ash are present. These intervals, interpreted as turbidites, also include reworked nannofossils from the Cretaceous and younger sediments.

The basal interval of the studied sequence, up to $98.38 \mathrm{rmcd}$, includes nannofossils indicative of the uppermost part of MNN16a biozone. Assemblages are characterized by the occurrence of Discoaster tamalis and Discoaster pentaradiatus, whereas $R$. pseudoumbilicus and Sphenolithus spp. are absent. According to the original definition of Rio et al. (1990), the upper boundary of this biozone coincides with the LO of $D$. tamalis. Low abundances of $D$. tamalis above 
Table 1. Planktonic foraminifer taxonomic units used for quantitative analyses.

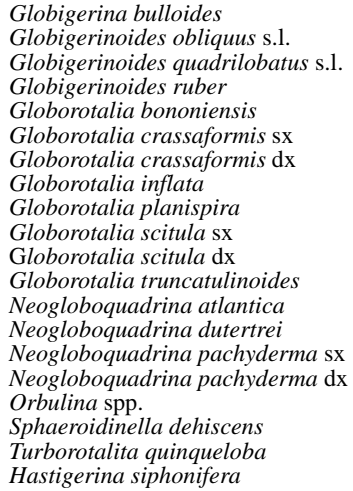

98.38 rmcd may be caused by reworking. Following Sprovieri et al. (1994), we recognize this boundary in coincidence of the last strong decrease in abundance (LCO) of D. tamalis, after the paracme interval that occurs in the highest part of its range (Fig. 7).

Between 98.38 and $85.54 \mathrm{rmcd}, D$. pentaradiatus and D. surculus co-occur up until the level in which discoasters abruptly decrease in abundance. In the two overlying samples, in which few discoasters occur, D. pentaradiatus is still present with relative high abundance values. In the two samples above this level, discoasters are rare and poorly preserved. Rare specimens of $D$. pentaradiatus and $D$. surculus are considered reworked because they co-occur with specimens of D. tamalis and Discoaster spp. that are surely reworked. Following Rio et al. (1990), we recognize the MNN16a-17/MNN18 boundary at $84.74 \mathrm{rmcd}$.

The MNN18 zone, defined at the top by the LO of Discoaster brouweri and Discoaster triradiatus, covers the interval between 84.74 and $61.30 \mathrm{rmcd}$. Along this biostratigraphic interval, these two taxa are the only indigenous discoasters. They are discontinuously present, with fluctuating relative abundance values. At $73.86 \mathrm{rmcd}$, the first abundance peak of $D$. triradiatus occurs. Above this level, high $(40 \%)$ relative abundance values of $D$. triradiatus vs. D. brouweri is discontinuously present up to $61.30 \mathrm{rmcd}$, the level at which $D$. triradiatus and D. brouweri disappear (Fig. 7). In the interval between 61.30 and $59 \mathrm{rmcd}$, badly preserved assemblages with reworked mid-Pliocene Discoasters occur. In the sample at 60.32 rmcd, two broken and one broken specimen of $D$. brouweri and $D$. triradiatus, respectively, are present but are considered reworked.

At 57.12 rmcd, medium-sized Gephyrocapsa first occur, and the base of the MNN19b Zone was identified. They co-occur with Calcidiscus macintyrei up to $54.92 \mathrm{rmcd}$, where the $\mathrm{LO}$ of $C$. macintyrei is recognized, because its abundance values decrease below the threshold of 1\% (Rio et al., 1990). Poorly preserved specimens of C. macintyrei are present with low abundance values in the two overlying samples, but they are considered reworked, because in this same samples nannofossil assemblages are badly preserved, in coincidence of turbiditic sediments.

Just above this turbiditic interval, at $49.72 \mathrm{rmcd}$, the first specimens of large Gephyrocapsa appear. Therefore, the MNN19c/ MNN19d boundary was recognized. They progressively increase in abundance up to $40.71 \mathrm{rmcd}$, where the LO of large Gephyrocapsa was detected (Fig. 7). The upper boundary of MNN19d was identified by this bioevent. The LO of Helicosphaera sellii, the alternative event for the definition of this boundary (Rio et al., 1990), occurs in the same sample.

The interval between 40.71 and $34.52 \mathrm{rmcd}$ is ascribed to the MNN19e zone, defined at the top by the FO of Gephyrocapsa sp. 3

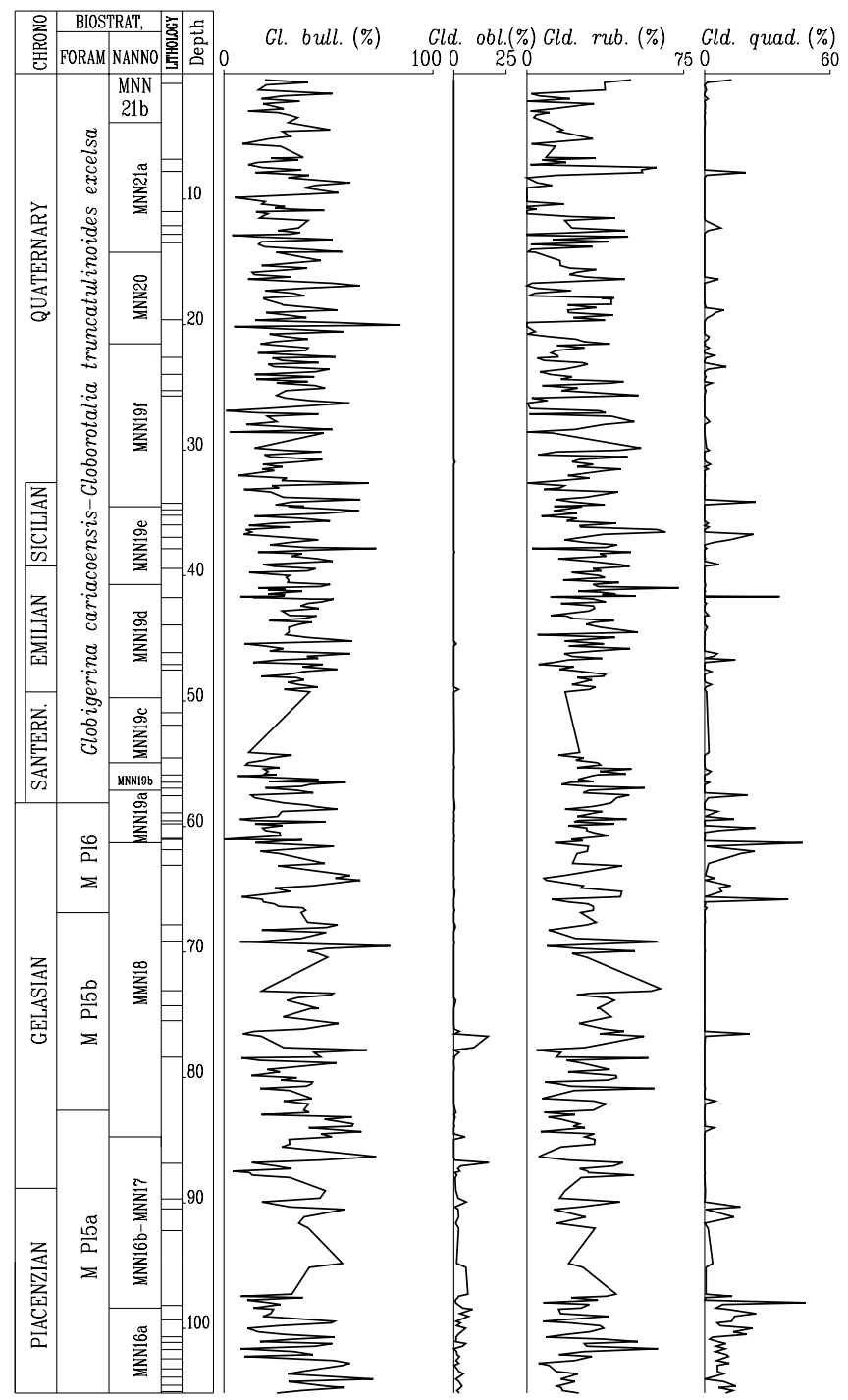

Figure 3. Relative abundance of planktonic foraminifer taxonomic units. $G l$. bull. $=$ Globigerina bulloides; Gld. obl. $=$ Globigerinoides obliquus; Gld rub. = Globigerinoides ruber; Gld. quad. $=$ Globigerinoides quadrilobatus.

and by the reappearance of the other medium-sized Gephyrocapsa. Within this interval, some broken and overgrown specimens of medium-sized and large Gephyrocapsa have been found with taxa reworked from older sediments.

The MNN19f zone, defined at its top by the LO of Pseudoemiliania lacunosa, covers the stratigraphic interval between 34.52 and 21.54 rmcd. Within this biozone, Gephyrocapsa sp. 3 is present, up to $24.86 \mathrm{rmcd}$, with large abundance fluctuations separated by short intervals in which it is absent.

The stratigraphic interval between 21.54 and $14.24 \mathrm{rmcd}$ is the MNN20 biozone, defined at its top by the FO of Emiliania huxleyi. This is the only bioevent that we identified, following Thierstein et al. (1977), by scanning electron microscope.

Above this level, E. huxleyi has low abundance values and is discontinuously present up to $3.9 \mathrm{rmcd}$, where it sharply increases in abundance, with percent values greater than $40 \%$. Consequently, the interval between 14.24 and 3.9 rmcd belongs to Biozone MNN21a, and the following interval up to the top of the sequence is referred to the Emiliania huxleyi Acme Zone, MNN21b. 


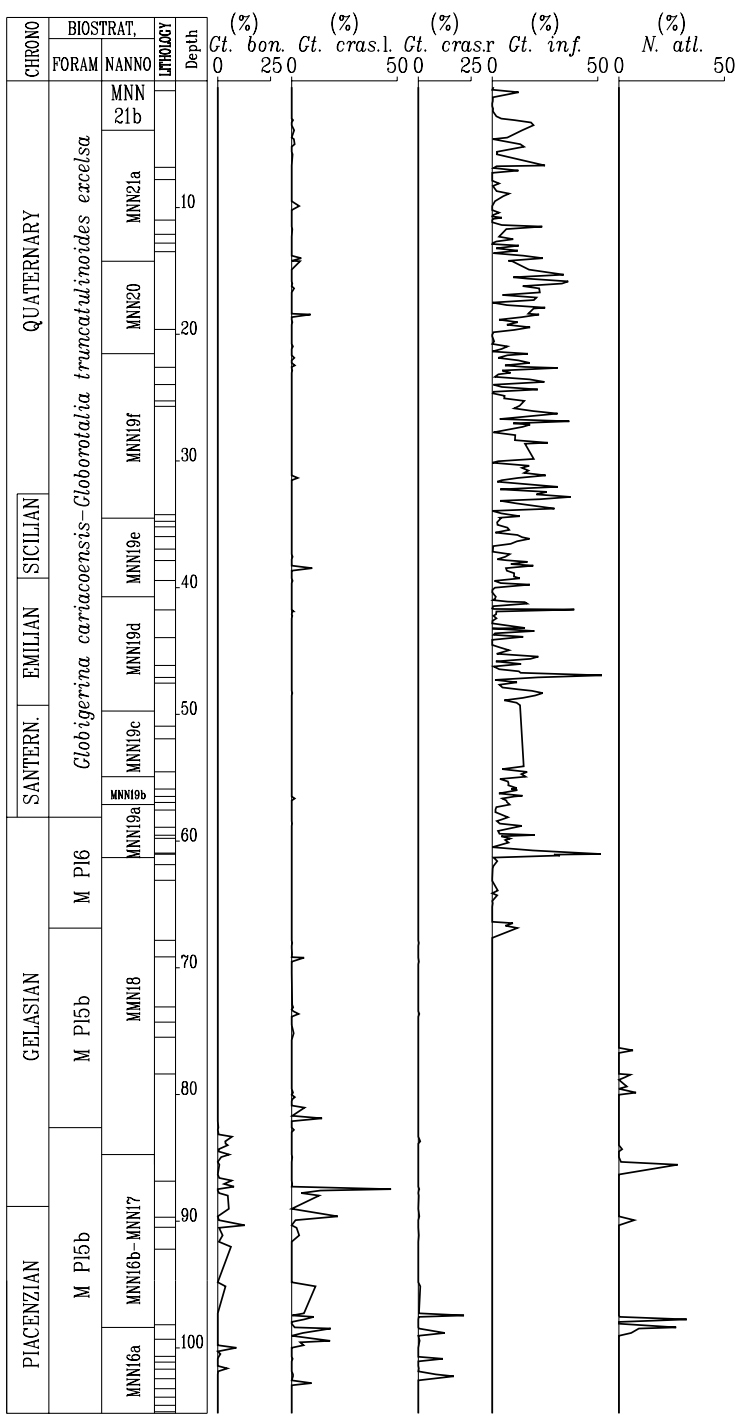

Figure 4. Relative abundance of planktonic foraminifer taxonomic units. Gt. bon. $=$ Globorotalia bononiensis $;$ Gt . cras. 1. = Globorotalia crassaformis left coiling; Gt. cras. r. = Globorotalia crassaformis right coiling; Gt. inf. $=$ Globorotalia inflata N. atl. = Neogloboquadrina atlantica .

\section{ISOTOPIC STRATIGRAPHY}

The $\delta^{18} \mathrm{O}$ of Globigerina bulloides is characterized by low-amplitude fluctuations in the lower portion of the record, moving towards more enriched values of $\delta^{18} \mathrm{O}$ and higher amplitude shifts with decreasing age. Significant enrichments occur after 3.2 Ma, before 2.53 $\mathrm{Ma}$, after $0.99 \mathrm{Ma}$ and after $0.46 \mathrm{Ma}$ and have previously been attributed to decreasing surface-water temperatures and increases in global ice volume (Thunell and Williams, 1983; Thunell et al., 1990). Increases in the amplitude of the $\delta^{18} \mathrm{O}$ signal are observed after 2.82 , $1.51,0.99$, and $0.46 \mathrm{Ma}$. The highest amplitude shifts are generally associated with sapropel events, with the largest shifts occurring after $0.46 \mathrm{Ma}$. Many workers have attributed these shifts to the reduction in surface-water salinity during the formation of sapropels in the Mediterranean (e.g. Williams et al., 1978; Rossignol-Strick et al., 1982; Vergnaud-Grazzini et al., 1986; Howell et al., 1990; Thunell et al., 1990), which may have triggered bottom-water anoxia through inhibiting the formation of the Mediterranean Deep Water. It should

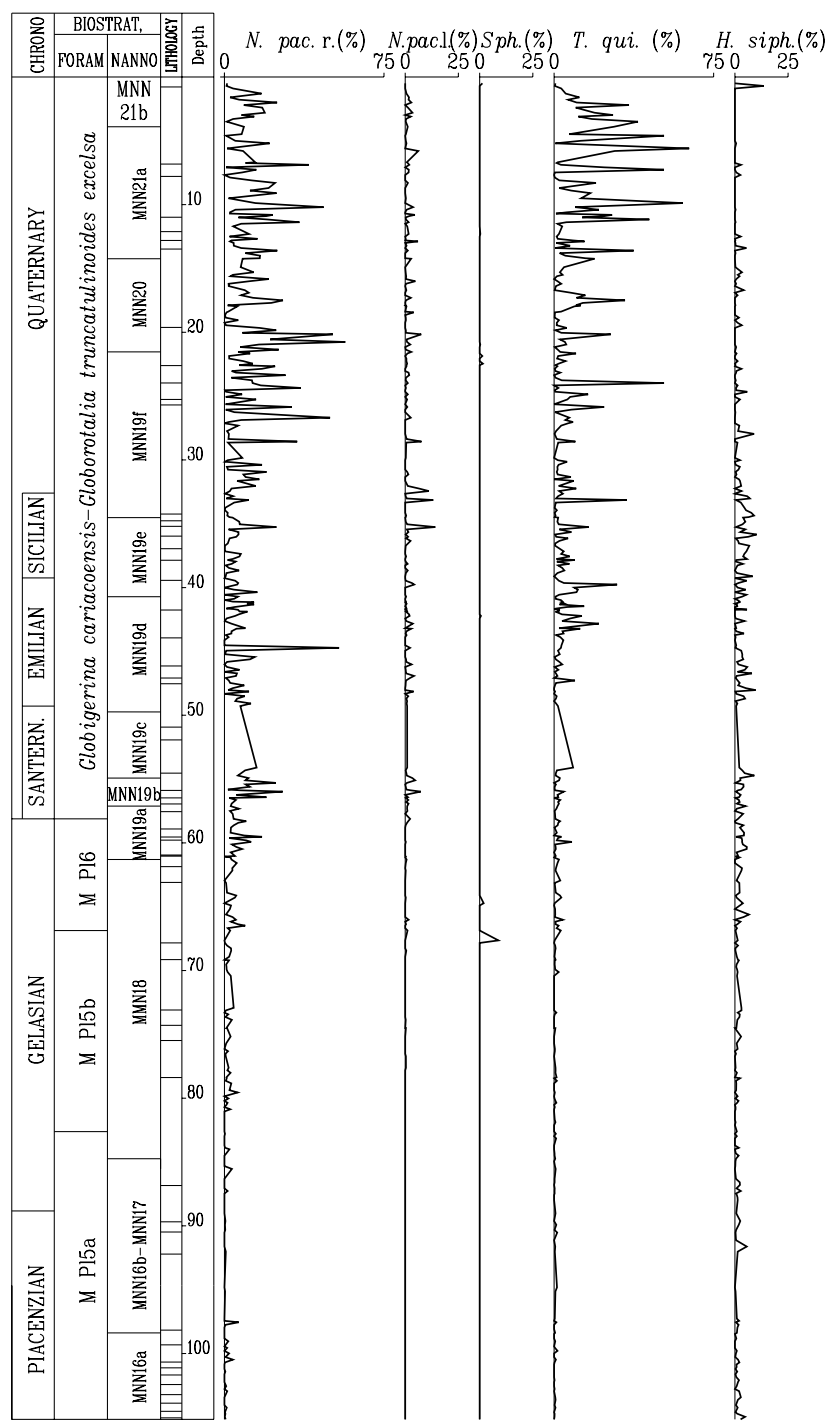

Figure 5. Relative abundance of planktonic foraminifer taxonomic units. $N$. pac. $\mathrm{r} .=$ Neogloboquadrina pachyderma right coiling; N. pac. $1 .=$ Neogloboquadrina pachyderma left coiling; Sph. = Sphaeroidinella dehiscens; $T$. qui. = Turborotalita quinqueloba; $H$. siph. = Hastigerina siphonifera.

be noted that Jenkins (1980) and Thunell et al. (1987) attribute these amplitude shifts to anomalously high Mediterranean surface-water salinities during glacial periods, as opposed to the formation of very low or "brackish" surface waters during the transition to interglacial conditions. A more detailed discussion and interpretation of all the isotopic results is provided in Howell et al. (Chap. 12, this volume).

\section{CYCLOSTRATIGRAPHY}

Apart from the 59 sapropel levels identified, 58 of which were included in the studied interval, no clear evidence of lithologic cyclicity was identified in the composite sequence. However, the relative abundance of the Globigerinoides spp. population regularly fluctuates, and these abundance fluctuations are forced by precession astronomical cycles in the Zanclean and main part of the Piacenzian and by obliquity astronomical cycles during the uppermost part of the Piacenzian, Gelasian, and lower Pleistocene (Sprovieri, 1992, 1993). 


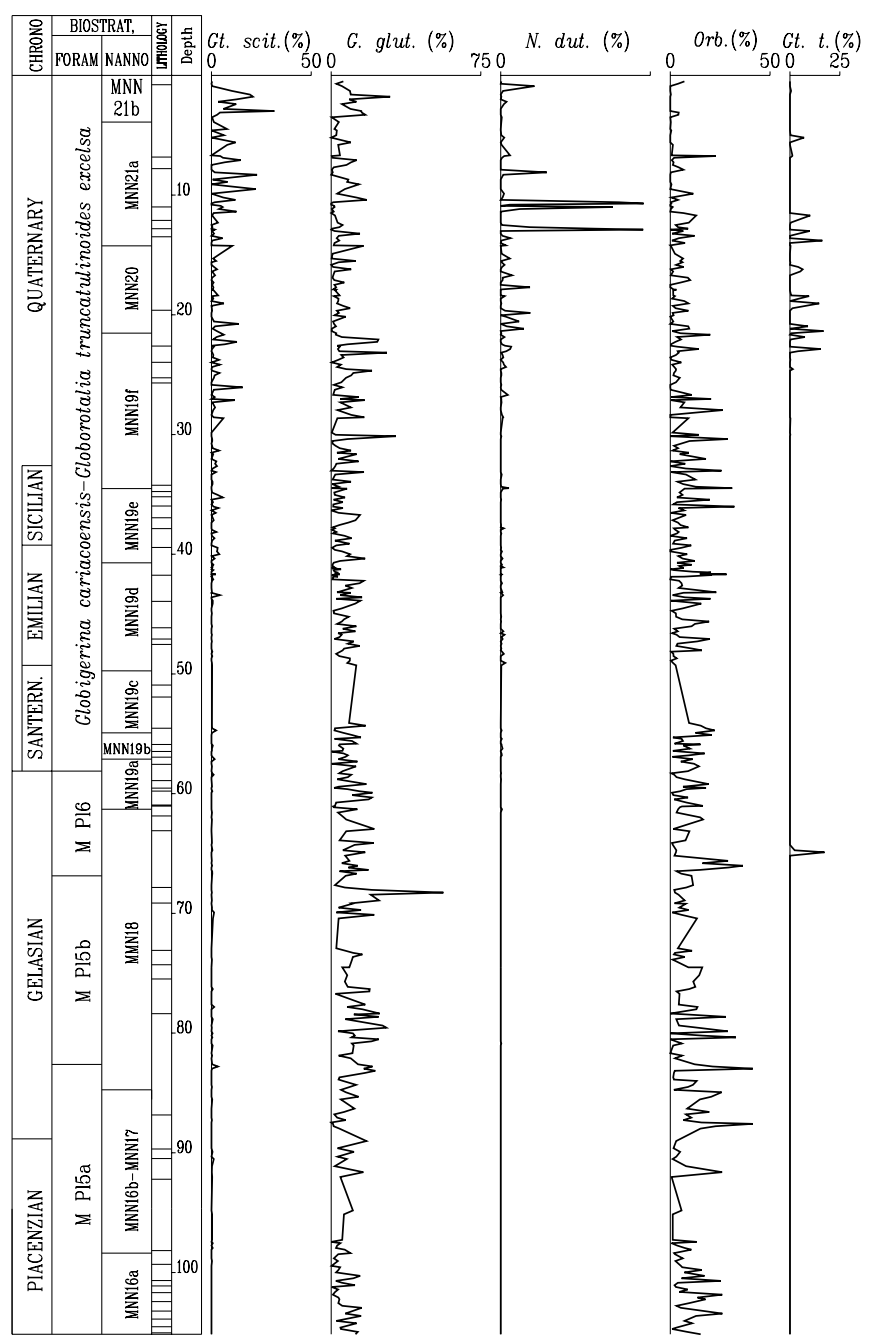

Figure 6. Relative abundance of planktonic foraminifer taxonomic units. Gt. scit. $=$ Globorotalia scitula $;$ G. glut. $=$ Globigerinita glutinata $;$ N. dut. $=$ Neogloboquadrina dutertrei; Orb. = Orbulina spp.; Gt. $t .=$ Globorotalia truncatulinoides.

Sprovieri (1993) numbered the relative abundance fluctuations correlated to the obliquity cycles, from younger to older stratigraphic levels, from fluctuation 22 (correlated to oxygen isotopic Stage 22) to fluctuation 64 at the Pliocene/Pleistocene boundary (approximated by the base of the $G$. cariacoensis Zone) to fluctuation 121 in the lower part of Biozone MPl5a. Even numbers were used to label decreased abundances, and odd numbers were used to label increased abundances. The most important calcareous plankton biostratigraphic events were correlated to the Globigerinoides spp. relative abundance fluctuations. Based on this correlation, the age of the relative abundance fluctuation/isotopic stage was proposed for every bioevent (Sprovieri, 1993).

Relative abundance of Globigerinoides spp. for Site 964 are reported in Figure 2, in which the abundance fluctuations are numbered and compared with the oxygen isotopic stages reported for Site 964 by Howell et al. (Chap. 13, this volume). The stratigraphic level (rmcd) of the abundance fluctuation and oxygen isotopic stages up to the base of the mid-Pleistocene are listed in Table 2. A good cycleby-cycle correlation exists between the two curves, with high relative abundance of Globigerinoides spp. occurring with the lighter oxygen isotopic values. Each abundance fluctuation was identified utilizing the well-established correlation of key biostratigraphic events with these Globigerinoides spp. relative abundance fluctuations (Sprovieri, 1993) and isotopic stages. The following correlations with the oxygen isotope stages are generally accepted: the LO of Pseudoemiliania lacunosa with isotopic Stage 12 (Thierstein et al., 1977; Vergnaud-Grazzini et al., 1990), the top of the large $G e$ phyrocapsa Zone (Biozone MNN19d) with isotopic Stage 37 (Raffi et al., 1993), the FCO of $N$. pachyderma left coiling with isotopic Stage 64 (Raymo et al., 1989; Lourens et al., 1992), the LO of Discoaster brouweri with isotopic Stage 71 (Raffi et al., 1993), the LO of Gt. bononiensis with isotopic Stage 96 (Lourens et al., 1992), and the sharp decrease of Discoaster population with isotopic Stage 100 (Rio et al., 1990; Thiedemann et al., 1994). In Figure 2, the first- and second-order calcareous plankton biostratigraphic events are reported for Site 964. Apart from the LO of D. brouweri, previously correlated by Sprovieri (1993) to abundance fluctuation 73 and now recognized in cycle 71 , the correlations between the biostratigraphic event and the relative abundance fluctuation are consistent with those proposed by Sprovieri (1993). With reference to the estimates by Shackleton et al. (1990) for selected oxygen isotopic stages and magnetic reversal boundaries, Table 3 provides the age of each biostratigraphic event within the approximated time interval of the correlative obliquity astronomical cycle. The ages proposed by Sprovieri (1993) and Lourens et al. (1996) are included for comparison in Table 3. The smaller differences between the ages proposed by Lourens et al. (1996) and this paper may be a consequence of the different references used for age evaluation (precession and obliquity astronomical cycles, respectively). The more consistent differences greater than $\sim 40 \mathrm{k} . \mathrm{y}$. are possibly due to different interpretations of the oxygen isotopic stratigraphy (Gt. inflata FO, Gt. truncatulinoides FO, Gephyrocapsa $>4 \mu \mathrm{m}$ FO, Gephyrocapsa $>5.5 \mu \mathrm{m}$ FO, and Gephyrocapsa sp. 3 FO) or to a different taxonomic concept of some species (according to our taxonomic concept of the species, the $N$. atlantica FO is recorded in the Mediterranean sections below, not above the $D$. tamalis LCO.)

A cyclostratigraphic interpretation of the Pliocene-lower Pleistocene stratigraphic interval was previously made for several Sicilian outcrops and for ODP Leg 107, Site 653 (Sprovieri, 1993). Results are reported in Figure 8, in which relative abundance fluctuations in the planktonic foraminifer assemblages of these sections are compared with the cyclostratigraphic results at Site 964.

The ages of the mid- and upper Pleistocene calcareous nannofossil bioevents were not calibrated by Sprovieri (1993). At Site 964, the LO of Gephyrocapsa sp. 3 is for the first time correlated to the oxygen isotopic Stage 15; the LO of P. lacunosa is correlated with isotopic Stage 12; the FO of E. huxleyi with isotopic Stage 8; and the initial increase of $E$. huxleyi with the transition between isotopic Stages 3 and 4 (Fig. 2). These results are comparable with those reported by Rio et al. (1990) in the Tyrrhenian basin and by Sanvoisin et al. (1993) for the $37.04 \mathrm{~m}$ long piston core $\mathrm{KC} 01 \mathrm{~B}$, raised from the Calabrian Ridge near the location of Site 964. Quantitative investigations on planktonic foraminifers, calcareous nannofossils, calcium carbonate, and grain-size distribution were carried out on 337 samples taken along this core, in which magnetostratigraphy was also obtained down to the base of the Jaramillo subchron.

The only Pliocene-lower Pleistocene land section from which oxygen isotope stratigraphy (based on the planktonic foraminifer Globigerinoides ruber) biostratigraphy, and magnetostratigraphy were published in the Mediterranean basin is the Singa section (Lourens et al., 1992, 1996). In Figure 9, results from the Singa section and Site 964 , and their proposed correlation, are plotted. Numbers in roman style indicate our interpretation, whereas numbers in italics and in parentheses indicate the original interpretation of Lourens et al. (1992). According to our interpretation, the two peaks of heavier isotopic values at about 105.45 and $102.95 \mathrm{~m}$ above the base of the section, assigned by Lourens et al. (1992) to one isotopic stage (74), are assigned to two different stages (74 and 76; Sprovieri, 1993). Conversely, the interval between 45 and $50 \mathrm{~m}$, assigned by Lourens et al. 


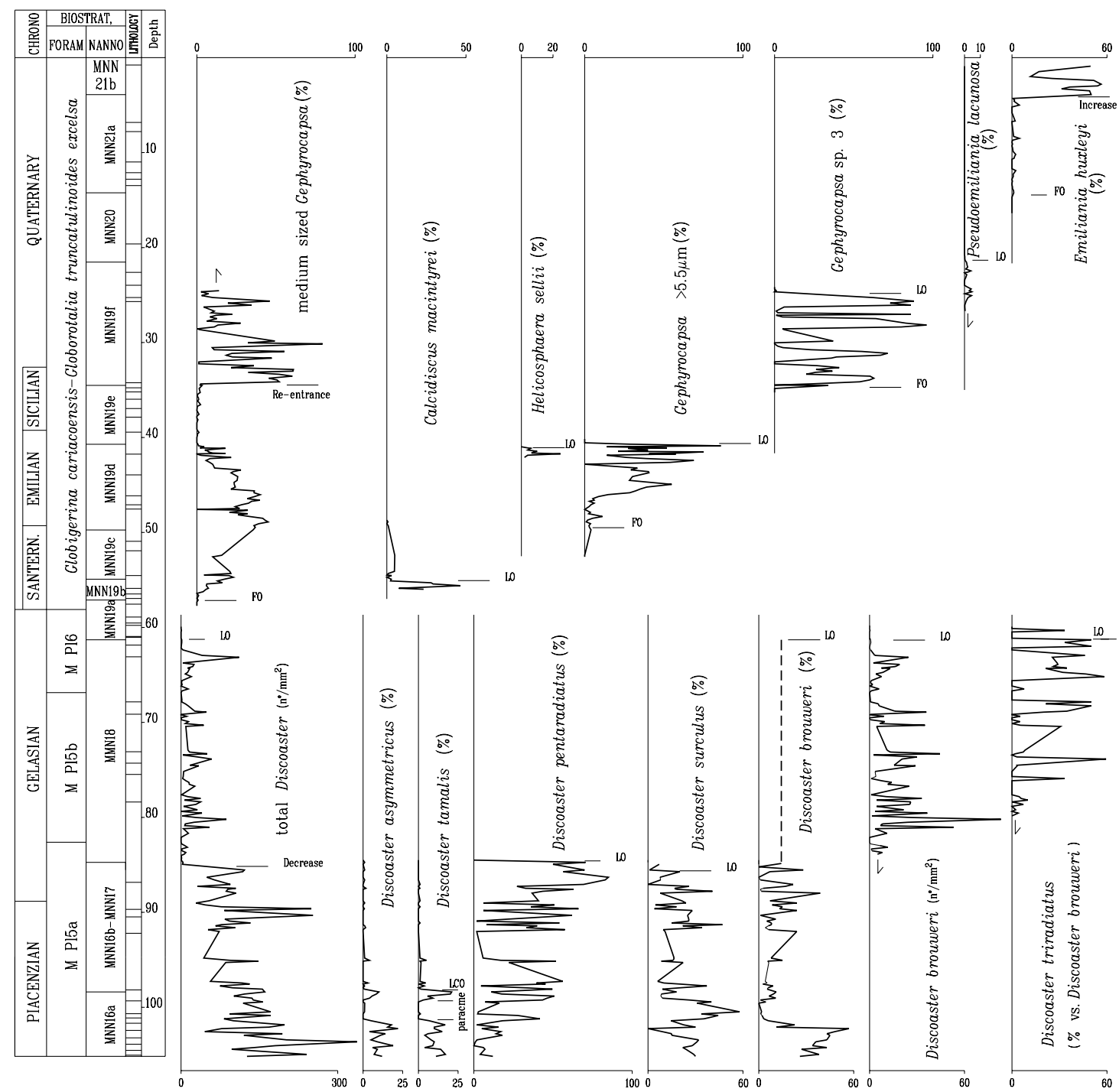

Figure 7. Relative abundance of calcareous nannofossil taxonomic units. Quantitative data for $D$. brouweri are given as percent values in the interval below the total Discoaster decrease (dashed line) and in number $/ \mathrm{mm}^{2}$ in the interval above the total Discoaster decrease.

(1992) to isotopic Stage 94, where no clear evidence of a shift to heavier values is present, is assigned entirely to isotopic Stage 95. In the lower Pleistocene interval, the isotopic stages were labeled only tentatively by Lourens et al. (1992). Our interpretation at Site 964 permits identification of these isotopic fluctuations, designating isotopic Stage 45 at the top of the sequence. This proposed correlation implies changes in the thickness of sediments in coincidence with some isotopic stages in the Singa section. The Singa section is an upper slope, terrigenous sequence where changes in the sediment accumulation rate can frequently occur. Anomalous, more or less long intervals with increased sediment accumulation rates are also present, and some coincide with relative abundance fluctuations of Globigerinoides spp., in the Monte San Nicola and Capo Rossello sections (Fig. 8).

\section{CHRONOSTRATIGRAPHY}

With reference to the recently accepted definition of the GSSP of the new Gelasian stage, which covers the upper part of the Pliocene (Rio et al., 1994), to the GSSP of the Neogene/Quaternary boundary at Vrica (Aguirre and Pasini, 1985), and to the proposed definition of the base of the Piacenzian (Cita et al., in press) and of the base of the Emilian substage (Pasini and Colalongo, 1994), we propose in this chapter the chronostratigraphic subdivision of the stratigraphic interval studied at Site 964.

The GSSP of the Piacenzian is defined using the small-scale lithologic cycle 77 of Hilgen (1991), identified at the base of the Punta Piccola section in southern Sicily. At the top of this lithologic cycle, the magnetostratigraphic boundary between the Gilbert and Gauss Chrons was identified. At the base of lithologic cycle 79, the LO of G. puncticulata occurs (Hilgen, 1991). The GSSP of the base of the Gelasian stage is defined in the Monte San Nicola section, near Gela (southern Sicily; Rio et al., 1994), in coincidence with a reddish laminated level correlated with oxygen isotopic Stage 103 and Mediterranean Precession Related Sapropel (MPRS) 250, and practically coincident with the Gauss/Matuyama boundary.

Several sapropels have been identified in the Pliocene-Pleistocene sequence at Site 964 (Sakamoto et al., Chap. 4, this volume). Most of them are also present in the Sicilian and Calabrian land sections, but a few of them are not present. Conversely, a small number of sapropels reported from these land sections are not present, or not 
Table 2. Depth of the relative abundance positive fluctuations of Globigerinoides spp. and the oxygen isotopic stages.

\begin{tabular}{|c|c|c|c|}
\hline $\begin{array}{l}\text { Globigerinoides spp. } \\
\text { abundance fluctuations }\end{array}$ & $\begin{array}{l}\text { Depth } \\
\text { (rmcd) }\end{array}$ & $\begin{array}{l}\text { Isotopic } \\
\text { stage }\end{array}$ & $\begin{array}{l}\text { Depth } \\
\text { (rmcd) }\end{array}$ \\
\hline 19 & $30.02-29.84$ & 19 & 30.14 \\
\hline 21 & 31.52 & 21 & 31.52 \\
\hline 23 & 32.84 & 23 & 32.84 \\
\hline 25 & $33.34-34.14$ & 25 & 33.94 \\
\hline 27 & $34.52-35.04$ & 27 & $34.52-35.04$ \\
\hline 29 & 35.84 & 29 & 35.84 \\
\hline 31 & $36.34-36.72$ & 31 & 36.72 \\
\hline 33 & 38.14 & 33 & 37.84 \\
\hline 35 & 39.12 & 35 & 38.86 \\
\hline 37 & $40.56-40.98$ & 37 & 40.71 \\
\hline 39 & $41.46-41.64$ & 39 & $41.68-41.72$ \\
\hline 41 & $42.10-42.82$ & 41 & 43.18 \\
\hline 43 & $43.60-44.52$ & 43 & 43.72 \\
\hline 45 & $45.46-45.82$ & 45 & 45.44 \\
\hline 47 & 46.72 & 47 & 47.08 \\
\hline 49 & 47.88 & 49 & 47.88 \\
\hline \multicolumn{4}{|l|}{ GAP } \\
\hline 55 & 54.54 & 55 & 54.48 \\
\hline 57 & $55.42-55.82$ & 57 & 55.88 \\
\hline 59 & 56.42 & 59 & 56.58 \\
\hline 61 & $56.92-57.12$ & 61 & 57.32 \\
\hline 63 & $57.50-57.72$ & 63 & 57.50 \\
\hline 65 & 58.80 & 65 & 58.80 \\
\hline 67 & 59.42 & 67 & 59.52 \\
\hline 69 & $59.80-60.32$ & 69 & 60.48 \\
\hline 71 & 61.30 & 71 & $61.02-61.30$ \\
\hline 73 & $61.98-62.16$ & 73 & 62.16 \\
\hline 75 & 63.14 & 75 & 63.14 \\
\hline 77 & 65.18 & 77 & 65.18 \\
\hline 79 & $65.81-66.68$ & 79 & 66.17 \\
\hline 81 & $67.84-69.20$ & 81 & 68.44 \\
\hline 83 & $69.92-73.12$ & 83 & $69.92-72.92$ \\
\hline 85 & $73.86-75.17$ & 85 & $75.17-73.86$ \\
\hline 87 & $76.52-76.72$ & 87 & 76.52 \\
\hline 89 & 78.41 & 89 & 78.41 \\
\hline 91 & 79.85 & 91 & 79.55 \\
\hline 93 & 80.87 & 93 & 80.69 \\
\hline 95 & $82.11-82-61$ & 95 & 82.52 \\
\hline 97 & $83.70-84.00$ & 97 & $83.33-83.70$ \\
\hline 99 & $84.50-84.94$ & 99 & $84.50-84.94$ \\
\hline 101 & $86.79-87.78$ & 101 & 87.88 \\
\hline 103 & & 103 & 88.82 \\
\hline 105 & $89.92-90.32$ & 105 & 90.15 \\
\hline 107 & 91.12 & 107 & $90.92-91.12$ \\
\hline 109 & 92.02 & 109 & $91.62-92.02$ \\
\hline \multicolumn{4}{|l|}{ GAP } \\
\hline 115 & 97.95-98.09 & 115 & 98.09 \\
\hline 117 & 99.04 & 117 & 99.04 \\
\hline 119 & 100 & 119 & 100.48 \\
\hline 121 & $100.86-101.42$ & 121 & $100.86-101.42$ \\
\hline
\end{tabular}

preserved, in the sequence at Site 964. Among these, MPRS 250, correlated with oxygen isotopic Stage 103, is not present (Fig. 2). Magnetostratigraphy is also not available at Site 964 . Therefore, the base of the Gelasian was recognized in this deep-sea sequence by the identification of oxygen isotopic Stage 103 at 88.82 rmcd (Table 2; Fig. 2). No biostratigraphic event occurs in coincidence with the base of the Gelasian. It can be identified with approximation by the LO of the calcareous nannofossils $D$. pentaradiatus and $D$. surculus, which occur in coincidence with oxygen isotopic stages 99 and 100, respectively, $\sim 80$ k.y. above the base of the Gelasian. It can also be identified by the LO of G. bononiensis (G. puncticulata of some authors), which occurs in oxygen isotopic Stage 96, 140 k.y. above the base of this chronostratigraphic unit. The segment at Site 964 between 105.16 and 88.82 rmcd is ascribed to the Piacenzian (upper part).

The top of the Gelasian is defined by the base of the Pleistocene coincident with oxygen isotopic Stage 65 . The base of the Pleistocene is generally recognized by the FCO of $N$. pachyderma left coiling, which occurs in oxygen isotope Stage 64 (Sprovieri, 1993; Lourens et al., 1992; Fig. 2), some 20 k.y. above the GSSP of the base of the Pleistocene. On the basis of the calcareous nannofossil assemblage, this chronostratigraphic boundary is approximated by the FO of medium-sized Gephyrocapsa. Therefore, the interval between 88.82 and $58.12 \mathrm{rmcd}$ at Site 964 is ascribed to the Gelasian.

Three substages, the Santernian, Emilian, and Sicilian, are generally used for the early Pleistocene by some stratigraphers in the Mediterranean basin. The Santernian was originally proposed by Ruggieri and Sprovieri (1977), the Emilian was redefined by Ruggieri et al. (1975), and the Sicilian was redefined by Ruggieri and Sprovieri (1975). Ruggieri et al. (1984) revised the chronostratigraphic classification of the lower Pleistocene, essentially with reference to the nannofossil biostratigraphy. On the basis of these papers, more recently Pasini and Colalongo (1994) proposed the GSSP of the base of the Emilian in coincidence with the lithologic level at which, in the Vrica section, Hyalinea baltica first appears (just below Sapropel p, in terms of Selli et al. [1977] nomenclature), practically coincident with the base of the large Gephyrocapsa (MNN19d) biozone (Pasini and Colalongo, 1982; Glaçon et al., 1990; Di Stefano et al., 1993). The base of the Sicilian is still waiting for a formal proposal of definition, and therefore this chronostratigraphic boundary is still recognized by the FO of Globorotalia truncatulinoides excelsa, as reported by Ruggieri et al. (1984). In some Sicilian sections and at ODP Leg 107, Site 653, the FO of $G$. truncatulinoides excelsa occurs in coin-

Table 3. Depth and proposed age of the identified bioevents.

\begin{tabular}{|c|c|c|c|c|c|c|}
\hline Bioevent & Depth & $\begin{array}{l}\text { Isotopic } \\
\text { stage }\end{array}$ & $\begin{array}{l}\text { Age } \\
(\mathrm{Ma})\end{array}$ & Source & $\begin{array}{l}\text { Lourens et } \\
\text { al. (1996) } \\
\text { (Ma) }\end{array}$ & $\begin{array}{l}\text { This paper } \\
\text { (Ma) }\end{array}$ \\
\hline Increase E. huxleyi $(\mathrm{N})$ & 3.9 & $3-4$ & & Sanvoisin et al. (1993) & & 0.057 \\
\hline FO E. huxleyi $(\mathrm{N})$ & 14.24 & 8 & 0.26 & Rio et al. (1990) & & 0.26 \\
\hline LO P. lacunosa $(\mathrm{N})$ & 21.54 & 12 & 0.46 & Rio et al. (1990) & & 0.46 \\
\hline LO Gephyrocapsa sp. $3(\mathrm{~N})$ & 24.86 & 15 & 0.584 & Castradori (1993) & & 0.58 \\
\hline FO Gephyrocapsa sp. $3(\mathrm{~N})$ & 34.52 & 27 & 0.99 & Sprovieri (1993) & & 0.99 \\
\hline LO Gephyrocapsa spp. $>5.5 \mu \mathrm{m}(\mathrm{N})$ & 40.71 & 37 & 1.25 & Sprovieri (1993) & 1.24 & 1.25 \\
\hline LO H. sellii $(\mathrm{N})$ & 41.14 & 37 & 1.25 & & 1.25 & 1.25 \\
\hline FO Gephyrocapsa spp. $>5.5 \mu \mathrm{m}(\mathrm{N})$ & 49.72 & 49 (51?) & 1.50 & Sprovieri (1993) & 1.61 & $1.50(1.54 ?)$ \\
\hline LO C. macintyrei $(\mathrm{N})$ & 54.92 & 56 & 1.62 & Sprovieri (1993) & 1.67 & 1.63 \\
\hline FO medium-size Gephyrocapsa $(\mathrm{N})$ & 57.12 & 61 & 1.75 & Sprovieri (1993) & 1.71 & 1.73 \\
\hline FCO $N$. pachyderma left $(\mathrm{F})$ & 58.12 & 64 & 1.81 & Sprovieri (1993) & 1.80 & 1.79 \\
\hline LO D. brouweri $(\mathrm{N})$ & 61.3 & 71 & 1.99 & Sprovieri (1993) & 1.95 & 1.95 \\
\hline LO D. triradiatus $(\mathrm{N})$ & 61.3 & 71 & 1.95 & & & 1.95 \\
\hline FO Gt. truncatulinoides $(\mathrm{F})$ & 64.9 & 77 & 2.07 & Sprovieri (1993) & 2.00 & 2.07 \\
\hline FO Gt. inflata $(\mathrm{F})$ & 66.86 & 80 & 2.13 & Sprovieri (1993) & 2.09 & 2.13 \\
\hline First abundance peak $D$. triradiatus $(\mathrm{N})$ & 73.86 & 85 & & & & 2.22 \\
\hline LO Gt. bononiensis $(\mathrm{F})$ & 82.61 & 96 & 2.45 & Sprovieri (1993) & 2.41 & 2.45 \\
\hline LO D. pentaradiatus $(\mathrm{N})$ & 84.74 & 99 & 2.51 & Sprovieri (1993) & 2.51 & 2.51 \\
\hline Discoaster decrease (N) & 85.54 & 100 & 2.53 & & & 2.53 \\
\hline LO D. surculus $(\mathrm{N})$ & 85.54 & 100 & 2.55 & & 2.53 & 2.53 \\
\hline LCO D. tamalis $(\mathrm{N})$ & 98.38 & 115 & 2.82 & Sprovieri (1993) & 2.83 & 2.82 \\
\hline FO $N$. atlantica $(\mathrm{F})$ & 98.82 & 116 & 2.83 & Sprovieri (1993) & 2.72 & 2.83 \\
\hline
\end{tabular}

Note: $(\mathrm{F})=$ planktonic foraminifer; $(\mathrm{N})=$ calcareous nannofossil. 


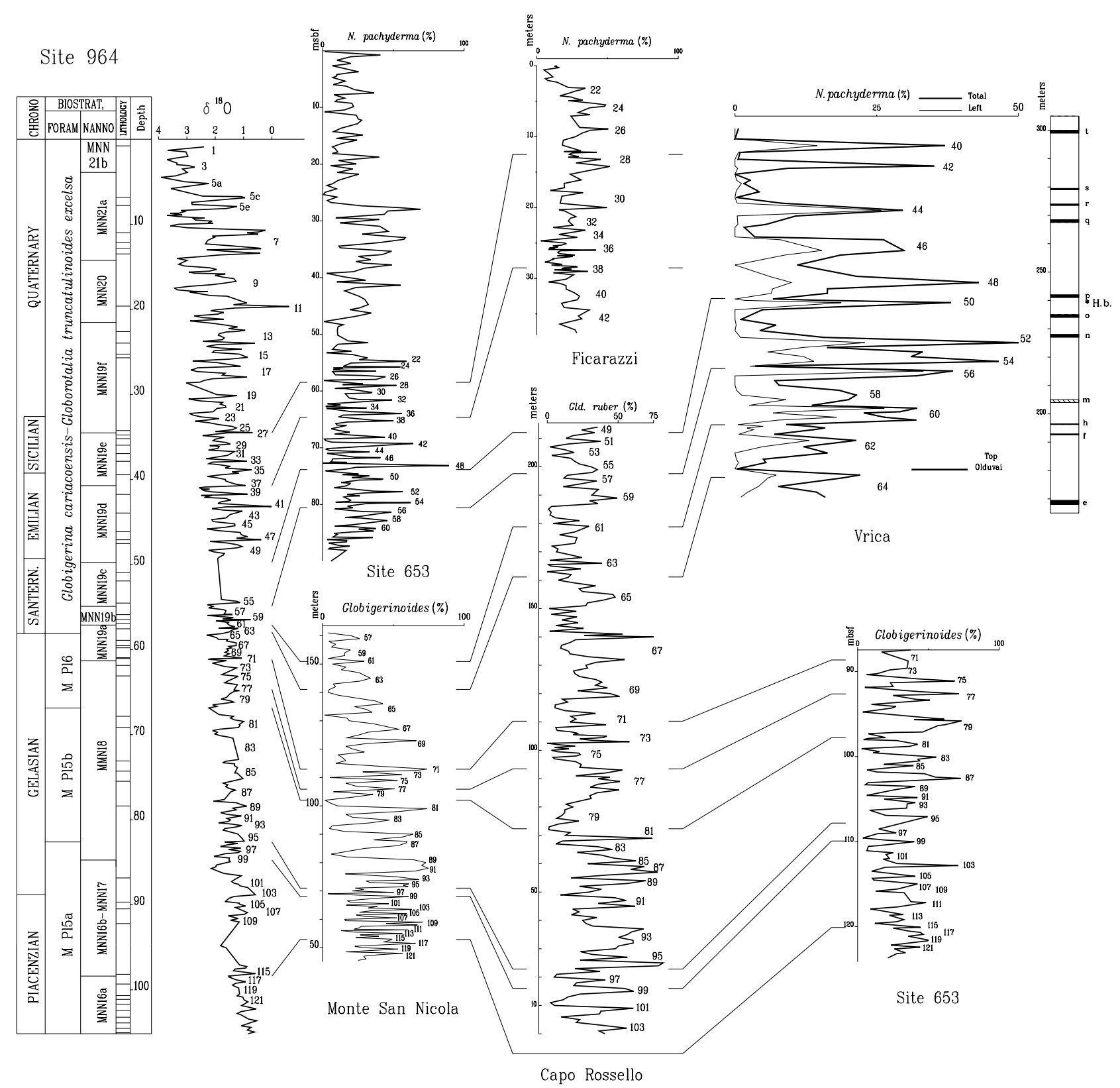

Figure 8. Correlation of the sequence at Site 964 to different Mediterranean sequences (amended from Sprovieri [1993]). H. b. = Hyalinea baltica.

cidence with oxygen isotopic Stage 35 (Sprovieri, 1993; VergnaudGrazzini et al., 1994). Because this taxon is usually rare or missing at this stratigraphic level (as at Site 964), this chronostratigraphic boundary may be well approximated by the base of the small Gephyrocapsa (MNN19e) biozone (Sprovieri, 1993), which occurs in oxygen isotopic Stage 37. Finally, the top of the Sicilian, coincident with the biocalcarenitic level that is rich in Arctica islandica and outcrops at Ficarazzi (type locality of the Sicilian), near Palermo (Sicily), is correlated with oxygen isotopic Stage 22 (Ruggieri et al., 1984; Vergnaud-Grazzini et al., 1994).

We therefore ascribe the interval between 58.12 and $49.72 \mathrm{rmcd}$ to the Santernian, the interval between 49.72 and $40.71 \mathrm{rmcd}$ to the Emilian, and the interval between 40.71 and 32.24 rmcd to the Sicilian. The sequence above this level is ascribed to the undistinguished Quaternary, with the segment between $\sim 8$ and 5 rmcd correlatable to oxygen isotopic Stages 5a-5e and ascribed to the Tyrrhenian Stage.

\section{CONCLUSIONS}

In the composite sequence of ODP Site 964, integrated calcareous plankton biostratigraphy and cyclostratigraphy, based on relative abundance fluctuations of Globigerinoides spp. and oxygen isotope stages, provided an accurate resolution of the stratigraphic interval between slightly below the LCO of $D$. tamalis and the Holocene. All biozones already recognized in coeval Italian land sections and in the Tyrrhenian basin were identified. Their boundaries are isochronous, at least within the approximation of the time interval defined by the abundance fluctuations and oxygen isotopic stages, which in the Pliocene and lower part of the Pleistocene are correlated to the obliquity astronomical cycles. Each bioevent coincides with the same fluctuation already identified in those sequences. Compared with the correlation proposed by Sprovieri (1993), the LO of D. brouweri, previously correlated to isotopic stage/fluctuation 73 , is now recognized in 


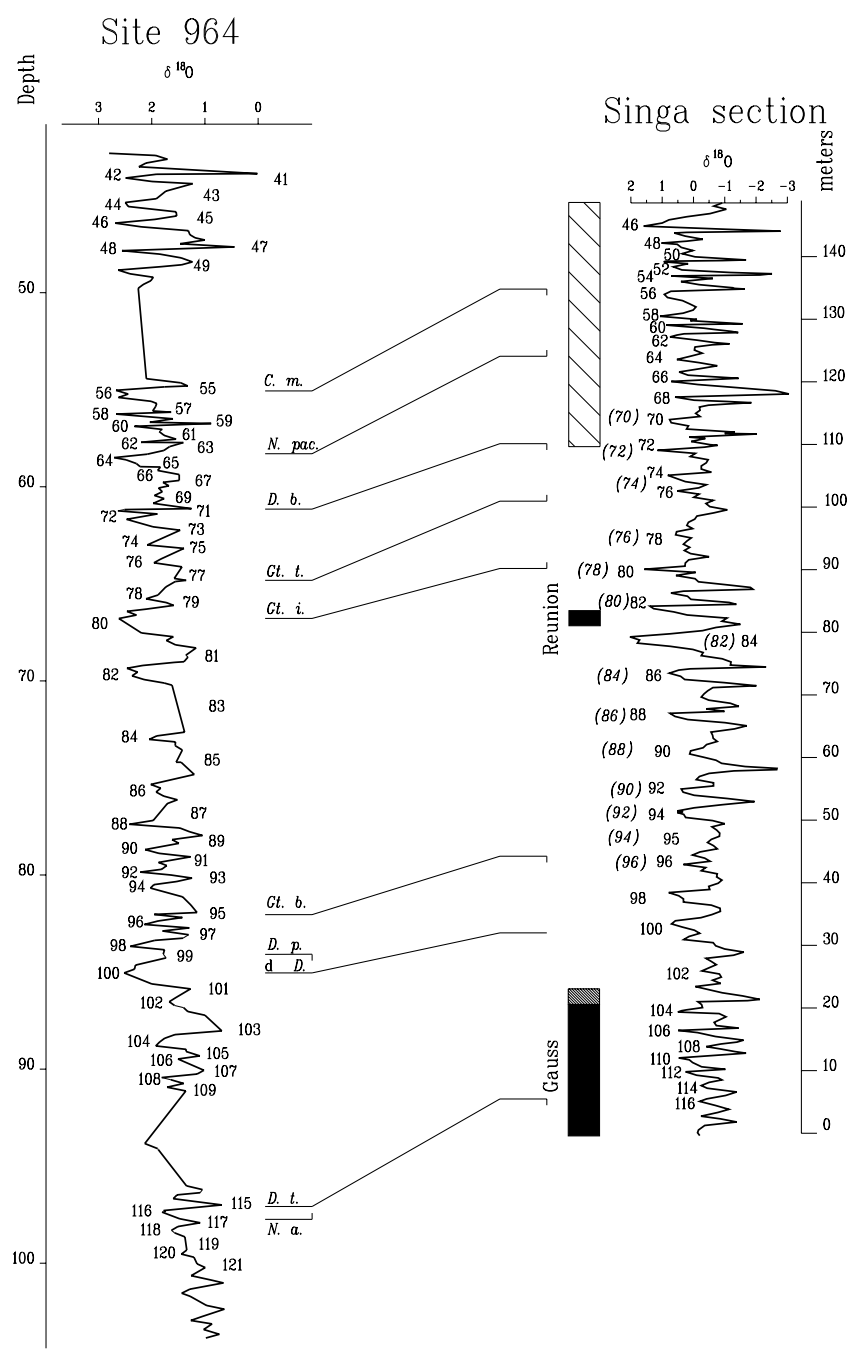

Figure 9. Proposed correlation between the sequence at Site 964 and the Singa section. Oxygen isotopic stages according to our interpretation are reported in roman type. Interpretation of Lourens et al. (1992) is reported in italics and parentheses. C. $m$. $=$ Calcidiscus macintyrei; N. pac. s. = Neogloboquadrina pachyderma left coiling; D. b. = Discoaster brouweri; Gt. t. = Globorotalia truncatulinoides; Gt. $i .=$ Globorotalia inflata $;$ Gt. $b .=$ Globorotalia bononiensis; D. p. $=$ Discoaster pentaradiatus; d. D. = Discoaster decrease; D. t. Discoaster tamalis; $N$. a. = Neogloboquadrina atlantica.

coincidence with relative abundance fluctuation/oxygen isotopic Stage 71.

All the chronostratigraphic units between the upper part of the Piacenzian and the Holocene were identified. The base of the Gelasian, recognized in coincidence with the oxygen isotope Stage 103, is not characterized at Site 654 by a sapropel level, which identifies the GSSP of the base of the Gelasian in the Monte San Nicola stratotype section.

\section{ACKNOWLEDGMENTS}

This paper was supported by MURST funds $40 \%$ to Sprovieri and by Mediterranean 2000 Funds to M.B. Cita. We thank M.B. Cita and J. Backmann for the scientific review of the manuscript and Elsa Kapitan-White, who patiently reviewed the editorial part of the manuscript.

\section{REFERENCES}

Aguirre, E., and Pasini, G., 1985. The Pliocene-Pleistocene boundary. Episodes, 8:11-120.
Castradori, D., 1993. Calcareous nannofossil biostratigraphy and biochronology in eastern Mediterranean deep-sea cores. Riv. Ital. Paleontol. Stratigr., 99:107-126.

Channell, J.E.T., Di Stefano, E., and Sprovieri, R., 1992. Calcareous plankton biostratigraphy, magnetostratigraphy and paleoclimatic history of the Plio-Pleistocene Monte S. Nicola section (Southern Sicily). Boll. Soc. Paleontol. Ital., 31:351-382.

Cita, M.B., 1973. Pliocene biostratigraphy and chronostratigraphy. In Ryan, W.B.F., Hsü, K.J., et al. Init. Repts. DSDP, 13 (Pt. 2): Washington (U.S. Govt. Printing Office), 1343-1379.

1975. Studi sul Pliocene e gli strati di passaggoi dal Miocene al Pliocene, VII. Planktonic foraminiferal biozonation of the Mediterranean Pliocene deep sea record: a revision. Riv. Ital. Paleontol. Stratigr., 81:527-544.

Cita, M.B., Rio, D., and Sprovieri, R., in press. The Pliocene Series: chronology of the type Mediterranean record and standard chronostratigraphy. In Wrenn, J.H., and Suc, J.P. (Eds.), Paleoecology, Climate and Sequence Stratigraphy of the Pliocene. Am. Assoc. Strat. Palin., Spec. Vol.

Di Stefano, E., Sprovieri, R., and Caruso, A., 1993. High resolution biochronology in the Monte Narbone Formation of the Capo Rossello section and the Mediterranean first occurrence of Globorotalia truncatulinoides. Riv. Ital. Paleontol. Stratigr., 99:357-370.

Glaçon, G., Rio, D., and Sprovieri, R., 1990. Calcareous plankton PliocenePleistocene biostratigraphy in the Tyrrhenian Sea (Western Mediterra- 
nean, Leg 107). In Kastens, K.A., Mascle, J., et al., Proc. ODP, Sci. Results, 107: College Station, TX (Ocean Drilling Program), 683-693.

Hilgen, F.J., 1991. Extension of the astronomically calibrated (polarity) time scale to the Miocene/Pliocene boundary. Earth Planet. Sci. Lett., 107:349-368.

Howell, M.W., Rio, D., and Thunell, R.C., 1990. Laminated sediments from the Vrica Section (Calabria, S. Italy): evidence for Plio-Pleistocene climatic change in the Mediterranean region. Palaeogeogr., Palaeoclimatol., Palaeoecol., 78:195-216.

Jenkins, J.A., 1980. An isotopic study of Nile Cone sediments and late Pleistocene sapropel formation in the eastern Mediterranean [M.S. thesis]. Univ. South Carolina, Columbia.

Lourens, L.J., Antonarakou, A., Hilgen, F.J., Van Hoof, A.A.M., VergnaudGrazzini, C., and Zachariasse, W.J., 1996. Evaluation of the Plio-Pleistocene astronomical timescale. Paleoceanography, 11:391-413.

Lourens, L.J., Hilgen, F.J., Gudjonsson, L., and Zachariasse, W.J., 1992. Late Pliocene to early Pleistocene astronomically forced sea surface productivity and temperature variations in the Mediterranean. Mar. Micropaleontol., 19:49-78.

Pasini, G., and Colalongo, M.L., 1982. Recent research on the Vrica section (Calabria, Italy): the proposed Neogene/Quaternary boundary-stratotype section [Report presented at the XI INQUA Congress, Moscow, 1982]

1994. Proposal for the erection of the Santernian/Emilian boundary-stratotype (lower Pleistocene) and new data on the Pliocene-Pleistocene boundary-stratotype. Boll. Soc. Paleont. Ital., 33:101-120.

Raffi, I., Backman, J., Rio, D., and Shackleton, N.J., 1993. Plio-Pleistocene nannofossil biostratigraphy and calibration to oxygen isotopes stratigraphies from Deep Sea Drilling Project Site 607 and Ocean Drilling Program Site 677. Paleoceanography, 8:387-408.

Raffi, I., and Rio, D., 1979. Calcareous nannofossil biostratigraphy of DSDP Site 132-Leg 13 (Tyrrhenian Sea-Western Mediterranean). Riv. Ital. Paleontol. Stratigr., 85:127-172.

Raymo, M.E., Ruddiman, W.F., Backman, J., Clement, B.M., and Martinson, D.G., 1989. Late Pliocene variation in Northern Hemisphere ice sheets and North Atlantic deep water circulation. Paleoceanography, 4:413446.

Rio, D., Raffi, I., and Villa, G., 1990. Pliocene-Pleistocene calcareous nannofossil distribution patterns in the Western Mediterranean. In Kastens, K.A., Mascle, J., et al., Proc. ODP, Sci. Results, 107: College Station, TX (Ocean Drilling Program), 513-533.

Rio, D., Sprovieri, R., and Di Stefano, E., 1994. The Gelasian stage: a proposal for a new chronostratigraphic unit of the Pliocene series. Riv. Ital. Paleontol. Stratigr, 100:103-124.

Rossignol-Strick, M., Nesteroff, W., Olive, P., and Vergnaud-Grazzini, C., 1982. After the deluge: Mediterranean stagnation and sapropel formation. Nature, 295:105-110.

Ruggieri, G., Buccheri, G., Greco, A., and Sprovieri, R., 1975. Un affioramento di Siciliano nel quadro della revisione della stratigrafia del Pleistocene inferiore. Boll. Soc. Geol. Ital., 94:889-914.

Ruggieri, G., Rio, D., and Sprovieri, R., 1984. Remarks on the chronostratigraphic classification of Lower Pleistocene. Boll. Soc. Geol. Ital., 103:251-259.

Ruggieri, G., and Sprovieri, R., 1975. La definizione dello stratotipo del piano Siciliano e le sue conseguenze. Riv. Min. Sic., 151-153.

Ruggieri, G., and Sprovieri, R., 1977. Ricerche sul Siciliano di Palermo: Le argille del fiume Oreto. Boll. Soc. Geol. Ital., 94:1613-1622.

Sanvoisin, R., d'Onofrio, S., Lucchi, R., Violanti, D., and Castradori, D., 1993. 1 Ma paleoclimatic record from the Eastern MediterraneanMARFLUX project: first results of a micropaleontological and sedimen- tological investigation of a long piston core from the Calabrian Ridge. Il Ouaternario, 6:169-188.

Selli, R., Accorsi, C.A., Mazzanti, M., Bertolani Marchetti, D., Bigazzi, G., Bonadonna, F.G., Borsetti, A.M., Cati, F., Colalongo, M.L., D’Onofrio, S., Landini, W., Menesini, E., Mezzetti, R., Pasini, G., Savelli, C., and Tampieri, R., 1977. The Vrica section (Calabria, Italy): a potential Neogene/Quaternary boundary stratotype. G. Geol., 42:181-204.

Shackleton, N.J., Berger, A., and Peltier, W.A., 1990. An alternative astronomical calibration of the lower Pleistocene timescale based on ODP Site 677. Trans. R. Soc. Edinburgh: Earth Sci., 81:251-261.

Sprovieri, R., 1992. Mediterranean Pliocene biochronology: a high resolution record based on quantitative planktonic foraminifera distribution. Riv. Ital. Paleontol. Stratigr., 98:61-100.

1993. Pliocene-early Pleistocene astronomically forced planktonic foraminifera abundance fluctuations and chronology of Mediterranean calcareous plankton bio-events. Riv. Ital. Paleontol. Stratigr., 99:371-414.

Sprovieri, R., Di Stefano, E., Riggi, A., and Busalacchi, P., 1994. La sezione intra-pliocenica di Gibil-Gabel (Caltanissetta, Sicilia centrale): un esercizio di biostratigrafia ad alta risoluzione. Boll. Soc. Paleont. It., 33:289298.

Thiedemann, R., Sarnthein, M., and Shackleton, N.J., 1994. Astronomic timescale for the Pliocene Atlantic ${ }^{18} \mathrm{O}$ and dust flux records of Ocean Drilling Program site 659. Paleoceanography, 9:619-638.

Thierstein, H.R., Geitzenauer, K., Molfino, B., and Shackleton, N.J. 1977. Global synchroneity of late Quaternary coccolith datum levels: validation by oxygen isotopes. Geology, 5:400-404.

Thunell, R.C., and Williams, D.F., 1983. The step-wise development of Pliocene-Pleistocene paleoclimate and paleoceanographic conditions in the Mediterranean: oxygen isotope studies and DSDP Site 125 and 132. In Meulencamp, J.E. (Ed.), Reconstruction of Marine Paleoenvironments. Utrecht Micropaleontol. Bull., 30:111-127.

Thunell, R.C., Williams, D.F., and Howell, M., 1987. Atlantic-Mediterranean water exchange during the late Neogene. Paleoceanography, 2:661-678.

Thunell, R.C., Williams, D., Tappa, E., Rio, D., and Raffi, I., 1990. PliocenePleistocene stable isotope record for Ocean Drilling Program Site 653, Tyrrhenian Basin: implications for the paleoenvironmental history of the Mediterranean Sea. In Kastens, K.A., Mascle, J., et al., Proc. ODP, Sci. Results, 107: College Station, TX (Ocean Drilling Program), 387-399.

Vergnaud-Grazzini, C., Devaux, M., and Znaidi, J., 1986. Stable isotope "anomalies" in Mediterranean Pleistocene records. Mar. Micropaleontol., 10:35-69.

Vergnaud-Grazzini, C., Capotondi, L., and Lourens, L., 1994. A refined Pliocene to early Pleistocene chronostratigraphic frame at ODP Hole 653A (West Mediterranean). Mar. Geol., 117:329-349.

Vergnaud Grazzini, C., Saliège, J.F., Urrutiaguer, M.J., and Iannace, A., 1990. Oxygen and carbon isotope stratigraphy of ODP Hole 653A and Site 654: the Pliocene-Pleistocene glacial history recorded in the Tyrrhenian Basin (West Mediterranean). In Kastens, K.A., Mascle, J., et al., Proc. ODP, Sci. Results, 107: College Station, TX (Ocean Drilling Program), 361-386.

Williams, D.F., Thunell, R.C. and Kennett, J.P., 1978. Periodic freshwater flooding and stagnation of the eastern Mediterranean Sea during the late Quaternary. Science, 201:252-254.

Date of initial receipt: 8 January 1997

Date of acceptance: 24 June 1997

Ms 160SR-010 